\title{
The Ability of Water Hyacinth (Eichhornia crasipes Mart.) and Water Lettuce (Pistia stratiotes Linn.) for Reducing Pollutants in Batik Wastewater
}

\author{
Bunyamin Muchtasjar ${ }^{1,4, *}$, Hadiyanto Hadiyanto ${ }^{2,4}$, Munifatul Izzati $^{3}$, \\ Zane Vincēviča-Gaile ${ }^{5}$, and Roy Hendroko Setyobudi ${ }^{6}$ \\ ${ }^{1}$ Department of Health Science, University of Muhammadiyah Purwokerto 53181, Indonesia \\ ${ }^{2}$ Department of Chemical Engineering, Diponegoro University, SH-Tembalang, \\ Semarang 50239, Indonesia \\ ${ }^{3}$ Department of Biology, Faculty of Mathematics and Natural Sciences, Diponegoro University, \\ SH-Tembalang, Semarang 50239, Indonesia \\ ${ }^{4}$ School of Postgraduate Studies, Diponegoro University, SH-Tembalang, Semarang 50239, Indonesia \\ ${ }^{5}$ Department of Environmental Science, University of Latvia, Jelgavas Street 1, Room 302, \\ Riga LV-1004, Latvia \\ ${ }^{6}$ Waste Laboratory, University of Muhammadiyah Malang, Jl. Raya Tlogo Mas No.246 \\ Malang 65144, Indonesia
}

\begin{abstract}
Batik produced by craftsmen is categorized as a small and medium industry. The problem of Batik production is less attention to the environment because the craftsmen lived in the middle of a residential area that has inexperience. One of less attention to the environment is no treatment of wastewater that reaches up to $95 \%(61.9 \mathrm{~L}$ each cloth $)$. Thus it polluted the river. This research aimed to treat the wastewater of Batik production by using phytoremediation. In this study, phytoremediation was carried out in three tanks in series using Eichhornia crassipes and Pistia stratiotes which are abundant in Indonesia. The treated wastewater was evaluated for its ammonia and chromium $(\mathrm{Cr})$. The results showed that ammonia reduced $78.36 \%$ by E. crassipes, and $73.13 \%$ P. stratiotes. While E. crassipes reduced $\mathrm{Cr}$ by $63.76 \%$ and $P$. stratiotes by $83.39 \%$. This research concluded that E. crassipes and P. stratiotes are potential plants to reduce the pollutants in Batik wastewater.
\end{abstract}

Keywords: Ammonia, chromium, phytoremediation, treatment.

\section{Introduction}

The role of small and medium-sized enterprises (SMEs) in economic development and growth is crucial in both developing and developed countries [1]. In Sokaraja, Indonesia there are some Batik SMEs that grow rapidly that collaborate as a society called 'Sawunggaling'. Those societies and other industries are located in the middle of residential

\footnotetext{
* Corresponding author: beben ump@yahoo.com
} 
areas. Inexperience is a main reason for less attention to the environment. None of these industries has wastewater treatment thus polluting the river.

Environmental pollution is living things, matter, energy, and other components that interfere into the environment by human activities, thus it converts environmental quality standards [2]. Environmental pollution from the batik industry can be identified from the solid color of wastewater disposal. The water usage in the Batik production $(61.9 \mathrm{~L}$ each cloth) is abundant and $95 \%$ as wastewater disposal generated from soaking, heating, and rinsing. The problem from Batik production involves high volumes of water and chemicals such as waxes and dyes.

These pollutants interfere with quality standards following the Indonesian Minister of Environment Regulation No. 5 of 2014, shown in Table 1.

Table 1. Comparison of wastewater batik quality and standards in Sokaraja, Indonesia

\begin{tabular}{|l|c|c|}
\hline \multicolumn{1}{|c|}{ Parameters } & $\begin{array}{c}\text { Quality of sample } \\
\left(\mathbf{m g ~ L}^{-\mathbf{1}}\right)\end{array}$ & $\begin{array}{c}\text { Quality standards } \\
\left(\mathbf{m g ~ L}^{\mathbf{- 1}} \mathbf{)}\right.\end{array}$ \\
\hline Biological Optical Density (BOD)5 & 2.5 & 60 \\
\hline Chemical Optical Density (COD) & 5.8 & 150 \\
\hline Total Suspended Solid (TSS) & 10.135 & 50 \\
\hline Total phenol & & 0.5 \\
\hline Total chrome (Cr) & 1.057 & 1.0 \\
\hline Total ammonia (NH3-N) & 278.681 & 8.0 \\
\hline Sulfide & 381.96 & 0.3 \\
\hline Oil and fat & 280 & 3.0 \\
\hline pH & 9.63 & 6.0 to 9.0 \\
\hline
\end{tabular}

From Table 1, it shows that some parameters have exceeded the quality standard threshold value. Even though there are regulations, the Batik industries ignore wastewater treatment because the punishment is too weak.

The phytoremediation model is simple, inexpensive, and easily operated [3]. Phytoremediation is considered to be a method for removing the pollutants in wastewater and recognized as a better green remediation technology using plants $[4,5]$ such as Water Hyacinth (Eichhornia crassipes Mart.) and Water Lettuce (Pistia stratiotes Linn.).

Water hyacinth is one of waterweed that uncontrollable growth but its nutrient absorption has provided a way for its usage in phytoremediation [4]. Moreover, Water Lettuce is a tropical plant that resists severe weather variability, fast reproduction, and simple manipulation. In addition, Water Lettuce is capable of remediating heavy metals [6]. The purpose of this study was to examine the E. crassipes and P. stratiotes plants in reducing pollutants in Batik industry wastewater. The pollutants indicated by ammonia and Chromium.

\section{Methods}

\subsection{Plant material}

The E. crassipes and P. stratiotes seedlings were conducted from the fish pond, in the region of Sokaraja, Banyumas, Central of Java, Indonesia. The seedlings were removed approximately $30 \mathrm{~d}$ growth because those plants are a perennial weed. The selection plants for this study based on their morphological character i.e green leaves and a stem length was $10 \mathrm{~cm}$. The greenhouse was used to expose plants getting natural light and ambient temperature. Those situations were close to their natural environment. Plants were 
separated and cultivated for $14 \mathrm{~d}$ before the experiment was carried out with sterile water to prevent contamination with other agents and to support the growth of roots, without fertilizer or additives.

\subsection{Experimental procedure}

This study used a phytoremediation model with three tanks made of multilevel arranged glass with a continuous drainage system, with a flow rate of $5 \mathrm{~L} \mathrm{~h}^{-1}$. The parameters observed in the treatment were ammonia and chromium.

The phytoremediation model was conducted on a laboratory scale in a greenhouse. Environmental factors were controlled by insect threats. The phytoremediation model is shown in Figure 1.

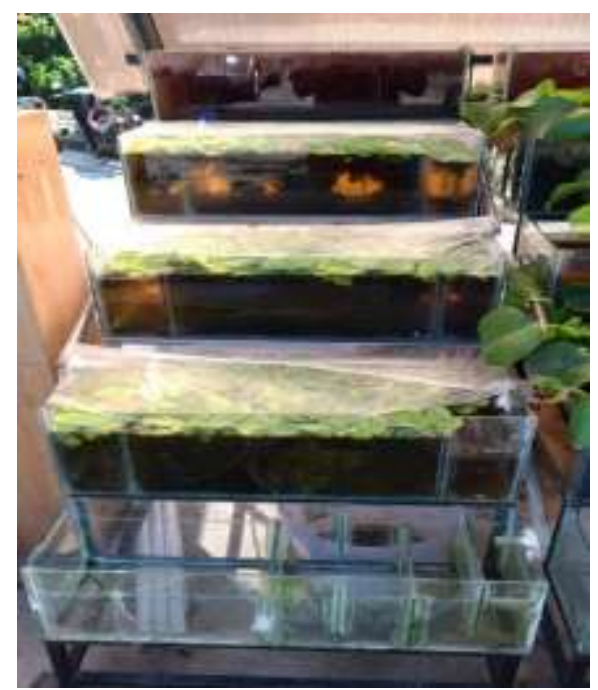

(A)

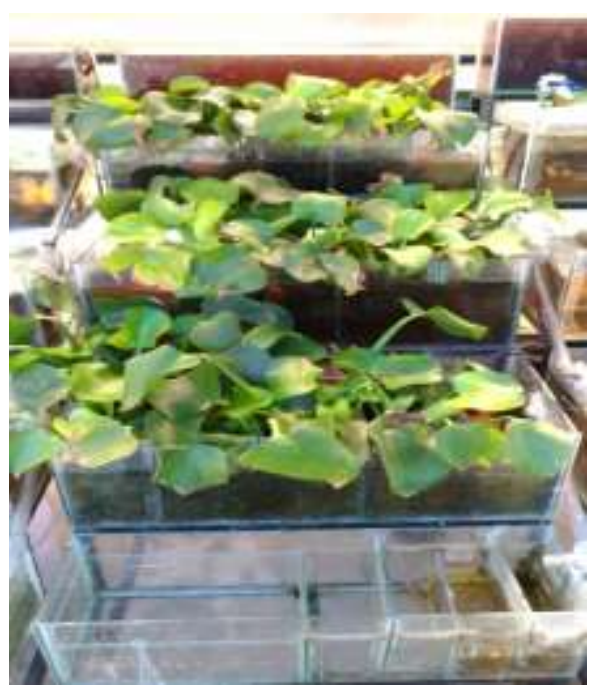

(B)

Fig.1. (A) Treatment with Eichhornia crassipes, (B) treatment with Pistia stratiotes.

\section{Results and discussions}

E. crassipes and P. stratiotes reduced pollutants in Batik wastewater $4 \%$ dilution. That high concentrations for $E$. crassipes and $P$. stratiotes were resistant. In the E. crassipes and $P$. stratiotes was used for the phytoremediation of the heavy metal, which affected leaf abnormalities, such as chlorosis and necrosis. This indicated that E. crassipes and $P$. stratiotes are more resistant to pollution agents proved by healthy plant and leaf quality was maintained even in the presence of high concentrations [7].

Before treatment of $4 \%$ Batik wastewater, it observed ammonia of $5.73 \mathrm{mg} \mathrm{L}^{-1}$ and $\mathrm{Cr}$ of $596 \mathrm{mg} \mathrm{L}^{-1}$. The E. crassipes and P. stratiotes grew in Wastewater for $15 \mathrm{~d}$, with a recirculation rate of $20 \mathrm{~L} \mathrm{~h}^{-1}$ decreased of ammonia, as shown in Figure 2. 


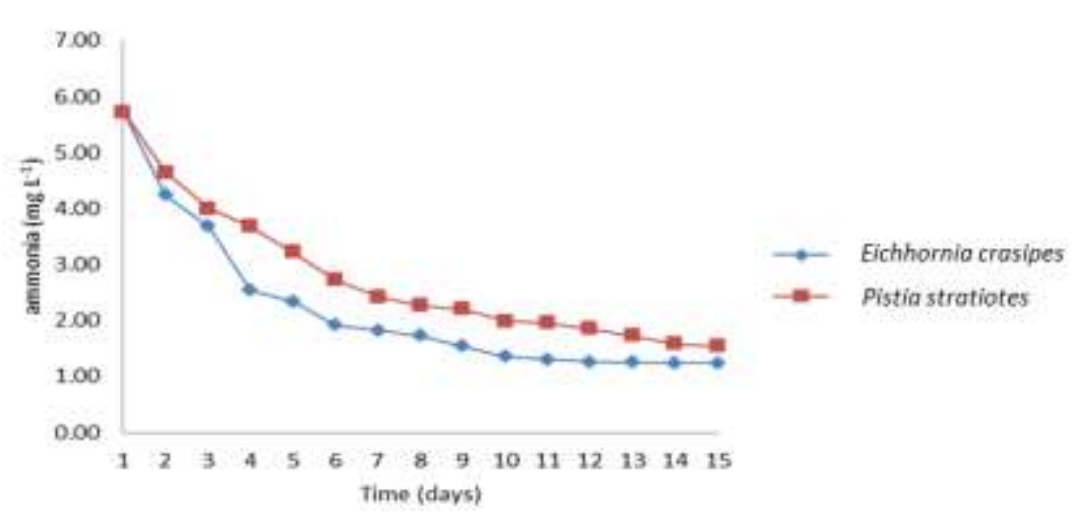

Fig.2. The decrease in ammonia parameters in Eichhornia crassipes and Pistia stratiotes.

Figure 2 showed that E. crassipes reduced ammonia reached up to $1.54 \mathrm{mg} \mathrm{L}^{-1}$ for $15 \mathrm{~d}$, equal to $78.36 \%$ and $1.24 \mathrm{mg} \mathrm{L}^{-1}$ or $73.13 \%$ by $P$. stratiotes. The decrease of ammonia is an indication of absorption by plants [8].

The results of the chromium in Batik wastewater treatment shown in Figure 3.

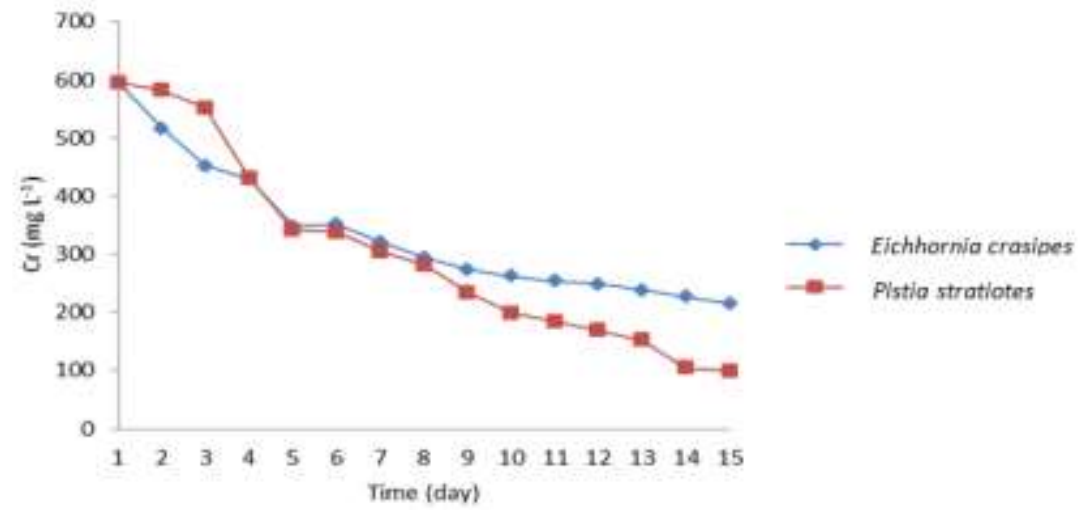

Fig.3. Decrease in Cr parameters in Eichhornia crasipes and Pistia stratiotes.

The decrease in chromium was $63.76 \%$ in E. crassipes and $83.39 \%$ in P. stratiotes. Both plants have hair-like roots that are used as a filter, tolerant, accumulate and eliminate environmental pollutants [6].

$E$. crassipes and $P$. stratiotes have shown their effectiveness in treating wastewater [9]. These plant species can sterilize higher heavy metals and help decontaminate soil, water, and others [5]. This also shows that the two plants have potential as bioindication and phytoremediation of contaminated aquatic environments [10]. In addition, Phytoremediation is related to the toxicity of heavy metals in contaminated ecosystems and bioremediation technology that is feasible, sustainable, and environmentally friendly [11]. This is in line with the results in the wastewater of his research Tewari et al. [12]. The impact of $\mathrm{Cr}$ contamination contained in Batik wastewater in physiology plants depends on metal speciation, which is responsible for mobilization, subsequent absorption and toxicity produced in plant systems [13]. 


\section{Conclusion}

This research concluded that E. crasipes and P. stratiotes plants reduced pollutants in Batik wastewater. The research indicated that the reduction of ammonia and Chromium were effective. Thus the two plants are potential adsorbent Ammonia and Chromium removal technology for wastewater treatment

Authors gratefully thank to the LPDP - Lembaga Pengelola Dana Pendidikan [Education Fund Management Agency] Number LPDP 20161141021636 of the Indonesian Ministry of Finance

\section{References}

1. R. Rahab, N. Anwar, R.E. Priyono. J. Comp. Int. Manag. 19,1:27-45(2016) https://journals.lib.unb.ca/index.php/JCIM/article/view/24610

2. Indonesia. Republik of Indonesia Law Number 32, 2009, concerning environmental protection and management. (2009). [in Bahasa Indonesia]

https://komisiinformasi.go.id/?p=1817

3. U. Tahir, A. Yasmin, U.H. Khan. J. King Saud Univ. Sci. 28,2:119-130(2016). https://www.google.com/url? sa=t\&rct=j\&q=\&esrc $=$ s\&source=web\&cd=\&cad=rja\&u act $=8 \& v e d=2$ ahUKEwiY5vGsteDqAhVYfX0KHetjBNEQFjAAegQIBBAB\&url=htt ps\%3A\%2F\%2Fcore.ac.uk\%2Fdownload\%2Fpdf\%2F82137348.pdf\&usg=AOvVaw 1vO7U6daapSwNg7HDMuRzY

4. S. Rezania, M. Ponraj, A. Talaiekhozani, S.E. Mohamad, M.F.M. Din, S.M. Taib, et al. J. Environ. Manag. 163:125-133(2015).

https://www.google.com/url?sa=t\&rct=j\&q=\&esrc=s\&source=web\&cd=\&cad=rja\&u act $=8 \& v e d=2$ ahUKEwi2i4HeteDqAhVBfH0KHewpCXAQFjAAegQIBRAB\&url $=$ ht tps\%3A\%2F\%2Fwww.ncbi.nlm.nih.gov\%2Fpubmed\%2F26311085\&usg=AOvVaw2 gApAJFEZEPyLU0BtEI-4q

5. A.R. Borker, A.V. Mane, G.D. Saratale, G.R. Pathade. Emir. J. Food Agric.

25,6:443-456(2013).

https://www.google.com/url?sa=t\&rct=i\&q=\&esrc=s\&source=web\&cd=\&cad=rja\&u act=8\&ved=2ahUKEwjE04K8tuDqAhXhmeYKHT6XBvYQFjAAegQIAxAB\&url= https $\% 3 \mathrm{~A} \% 2 \mathrm{~F} \% 2 \mathrm{Fwww}$.researchgate.net $\% 2 \mathrm{Fpublication} \% 2 \mathrm{~F} 271305647$ Phytoreme diation_potential_of_Eichhornia_crassipes_for_the treatment_of_cadmium_in_relati on_with_biochemical_and_water_parameters\&usg=AOvVaw28YKypTG3v7SykliBa $\underline{\mathrm{U} 01 \mathrm{~T}}$

6. E. Agostini, M.A. Talano, P.S. González, A.L.W. Oller, M.I. Medina. Appl. Microbiol. Biotechnol. 97:1017-1030(2013).

https://www.google.com/url?sa=t\&rct=j\&q=\&esrc $=$ s\&source=web\&cd $=\&$ cad $=r j a \& u$ $\underline{\text { act }=8 \& v e d=2 \text { ahUKEwiOsMfbtuDqAhWCheYKHTR3COIQFjAAegQIBxAB\&url=h }}$ ttps\%3A\%2F\%2Fpubmed.ncbi.nlm.nih.gov\%2F23287856\%2F\&usg=AOvVaw1bKp 0aC9TyyiipR6B1Lqhy

7. D.F. Escoto, M.C. Gayer, M.C. Bianchini, G. da C. Pereira, R. Roehrs, E.L.G.

Denardin. Chemosphere, 227:299-304(2019).

https://www.google.com/url?sa=t\&rct $=\mathrm{j} \& \mathrm{q}=\&$ esrc $=$ s\& source $=$ web\&cd $=\&$ cad $=r j a \& u$ act $=8$ \&ved $=2$ ahUKEwit9-Cet-

DqAhXtILcAHR8EARcQFjAAegQIBBAB\&url=https\%3A\%2F\%2Feuropepmc.org \%2Farticle\%2Fmed\%2F30999171\&usg=AOvVaw109Fo_AuTvgWUkQeCL20-q

8. K. Sung, G.J. Lee, C. Munster. Int. J. Phytoremediation. 17,10:936-944(2015). https://doi.org/10.1080/15226514.2014.1003791 
9. C.O. Akinbile, M.S. Yusoff. Int. J. Phytoremediation. 14,3:201-211(2012). https://www.google.com/url? sa=t\&rct=j\&q=\&esrc $=$ s\&source $=$ web $\& c d=\& c a d=r j a \& u$ act $=8$ \&ved $=2$ ahUKEwjbhK64t-

DqAhVE9XMBHelYCPEQFjAAegQIARAB\&url=https\%3A\%2F\%2Fwww.research gate.net\%2Fpublication\%2F224923917_Assessing_Water_Hyacinth_Eichhornia_cra ssipes_and_Lettuce_Pistia_stratiotes_Effectiveness_in_Aquaculture_Wastewater_Tr eatment\&usg $=\mathrm{AOvV}$ aw3w64z5UlwvClUxS3nPpQ2C

10. F. Farnese, J. Oliveira, F. Lima, G. Leão, G. Gusman, L. Silva.

Braz. J. Biol. 74,3suppl 1:S108-S112(2014).

https://www.google.com/url? sa $=$ t\&rct $=\mathrm{j} \& \mathrm{q}=\&$ esrc $=$ s\& $\&$ source $=$ web $\& \mathrm{~cd}=\& \mathrm{cad}=\mathrm{rja} \& \mathrm{u}$ act $=8 \& v e d=2$ ahUKEwiRkOzUt-

DqAhUCjuYKHSREAqIQFjAAegQIBRAB\&url=https\%3A\%2F\%2Fwww.scielo.br \%2Fscielo.php\%3Fpid\%3DS1519-

69842014003000013\%26script\%3Dsci_arttext\&usg=AOvVaw1mDg_4PDYx7Qtgz VYEQ7yJ

11. D. Mani, C. Kumar. Int. J. Environ. Sci. Technol. 11:843-872(2014).

https://www.google.com/url? sa=t\&rct=j\&q=\&esrc=s\&source=web\&cd=\&cad=rja\&u act $=8 \& v e d=2$ ahUKEwi5s7Trt-

DqAhXq7XMBHefJCG0QFjAAegQIBBAB\&url=https\%3A\%2F\%2Flink.springer.c om\%2Farticle \%2F $10.1007 \% 2$ Fs $13762-013-0299-$

8\&usg=AOvVaw31gmaoZX3pp6KMx7UhSb-u

12. A. Tewari, R. Singh, N.K. Singh, U.N. Rai. Bioresour. Technol. J., 99:8715-8721(2008).

$\underline{\text { https: } / / \text { www.google.com/url? } \mathrm{sa}=\mathrm{t} \& \mathrm{rct}=\mathrm{j} \& \mathrm{q}=\& \mathrm{esrc}=\mathrm{s} \& \text { source }=\text { web\&cd }=\& \mathrm{cad}=\mathrm{rja} \& \mathrm{u}}$ act $=8$ \&ved $=2$ ahUKEwjVhv-

BuODqAhU18HMBHSX1AIkQFjAAegQIBRAB\&url=https\%3A\%2F\%2Fwww.aca demia.edu\%2F5875680\&usg=AOvVaw0V2shz_eF7gc_1P0CrBu_t

13. M. Junaid, M. Adnan, N. Khan, M. U. Rahman, N. Ali. Fuuast J. Biol.

3,2:95-103(2013).

https://www.google.com/url? sa $=t \& r c t=j \& q=\& e s r c=s \&$ source $=$ web\&cd $=\& c a d=r j a \& u$ act=8\&ved=2ahUKEwjM8IuxuODqAhVBIbcAHdhlCUgQFjABegQIBRAB\&url=ht tps $\% 3 \mathrm{~A} \% 2 \mathrm{~F} \% 2 \mathrm{Fwww}$. researchgate.net $\% 2 \mathrm{Fprofile} \% 2 \mathrm{FArvin}$ Singh $56 \% 2 \mathrm{Fpost} \% 2$ FMethod_for_plant_growth_measurement_for_Brassica $\% 2$ Fattachment $\% 2 \mathrm{~F} 59 \mathrm{~d} 64 \mathrm{eb}$ d79197b80779a8076\%2FAS\%253A494301905944576\%25401494862166949\%2Fd ownload\%2F95-103.pdf\&usg=AOvVaw1K8PBhMbmdnrtQivoCAfl6 